\title{
The clavobranchialis musculature in sarcopterygian fishes, and contribution to osteichthyan feeding and respiration
}

\author{
Zerina Johanson \\ Palaeontology, Australian Museum, 6 College Street, Sydney, NSW 2010, Australia, \\ e-mail: zerinaj@austmus.gov.au
}

Keywords: Clavobranchìales, Sarcopterygii, Actinopterygii, Chondrichthyes, coracobranchiales, Dipnoi, Neoceratodus, Strepsodus

\begin{abstract}
Various fossil lungfish taxa preserve distinct depressions on the smooth postbranchial lamina of the dermal pectoral girdle. These depressions are largely unknown in other sarcopterygian fishes, but are present in the rhizodont sarcopterygian Strepsodus. Comparisons with extant actinopterygian fishes suggest these depressions mark the point of origin for the clavobranchialis musculature, extending anterodorsally into the gill chamber to insert on the ventral surface of the ceratobranchial(s). Studies examining feeding and respiratory mechanisms of bony fishes (Osteichthyes) have emphasised the role of mandibular depression in generating negative pressures within the oral cavity to draw in water/air/food via suction. However, phylogenetically basal actinopterygians, fossil lungfish and other fossil sarcopterygians (such as Strepsodus) lack the apomorphies that increase suction among bony fishes. In these taxa the clavobranchialis muscles may serve to augment this negative pressure by retracting the ceratobranchials and increasing the size of the oral/ oropharyngeal cavity. $A$ comparable action is performed by the chondrichthyan coracobranchiales muscles, particularly during feeding, and the function of these ventral gill arch muscles is likely to be a synapomorphy of jawed vertebrates (Gnathostomata). This musculature is absent from jawless vertebrates such as the Osteostraci.
\end{abstract}

\section{Contents}

Introduction

Materials and methods

$\alpha$

The dermal pectoral girdle of fossil sarcopterygians and associated muscle attachments

The role of the clavobranchialis in feeding and respiration

Discussion

Conclusions

Acknowledgements

References

\section{Introduction}

Muscles originating on the pectoral girdle and inserting anteriorly on the mandible and branchial arches depress or lower the mandible, hyoid arch, and more posterior gill arches. Of these muscles, much of the research into gnathostome (jawed vertebrates) feeding and respiration has focused on the sternohyoideus and coracomandibularis. The sternohyoideus (= rectus cervicus) attaches to the ventral portions of the hyoid arch and lowers the mandible via the mandibulohyoid ligament, the latter running between the dorsal ceratohyal and the rear of the mandible (Lauder, 1979, 1980, 1982, 1983a, b, 1985; Lauder \& Shaffer, 1985; Bemis, 1987; Bemis \& Lauder, 1986; Shaffer \& Lauder, 1985; Reilly \& Lauder, 1990). This was described as a generalised mechanism for the Gnathostomata, occurring in acanthodians, actinopterygians, extant lungfishes, coelacanths (the latter two groups representing the piscine Sarcopterygii) and aquatic salamanders (Lauder, 1980, 1982, 1985; Bemis \& Lauder, 1986; Campbell \& Barwick, 1987, 1988a, 1999; Maisey, 1989; Reilly \& Lauder, 1990). Attachment surfaces for the sternohyoideus muscle and mandibulohyoid ligament are also preserved in various fossil sarcopterygian taxa including Eusthenopteron (Jarvik, 1980), Gogonasus (Long et al., 1997: figs 39, 48B, D), Medoevia (Lebedev, 1995: fig. 18B), Glyptolepis (Jarvik, 1972: fig. 28), and several fossil lungfishes (Miles, 1977; Wang et al., 1993; Campbell \& Barwick, 1988a, 2002; Barwick \& Campbell, 1996; - KSW Campbell, pers. comm. 2002). However, recent research on the chondrichthyan musculature 
questioned the function of the mandibulohyoid ligament in this group. Rather, the main muscle lowering the mandible was the coracomandibularis, inserting at the symphysis of the chondrichthyan lower jaw (Wilga et al., 2000).

As the mandible is lowered and the mouth opened, negative pressure (suction) created within the oral cavity draws in aerated water (or air) and food materials. Mandibular depression was said to create the greatest change in the volume of the oral cavity and provide the greatest contribution to this negative pressure (Lauder, 1985). Additionally, actinopterygians (e.g., Alexander, 1969, 1970; Liem, 1970; Lauder, 1983b), lepidosirenid lungfish (Protopterus and Lepidosiren (Bemis, 1987; Bemis \& Lauder, 1986)) and aquatic salamanders (Lauder \& Shaffer, 1985) modify various aspects of their jaws, skull, gill arch, pectoral girdle and muscle morphology to increase negative pressure generated within the oral cavity. These modifications serve to increase the flow of water/air into the mouth, improving the efficiency of both respiration and feeding. By comparison, fossil sarcopterygians (including non-lepidosirenid lungfish) appear to lack these modifications, as do fossil and phylogenetically basal actinopterygians (Lauder, 1980, 1982), and the negative pressure generated within the mouth cavity of these taxa was considered to be relatively low (Lauder, 1980).

However, little consideration has been given in these discussions to the musculature responsible for depressing the more posterior gill arches, and its role in expanding and increasing the volume of the oropharyngeal cavity during the initial stages of feeding and respiration. These muscles, including the clavobranchiales in osteichthyans and the coracobranchiales in chondrichthyans, originate on (or in association with) the pectoral girdle and insert on the ventral surfaces of the branchial arches (ceratobranchials). Experimental evidence indicates that the chondrichthyan coracobranchiales act to depress the branchial basket during feeding (Moss, 1977; Mallatt, 1996; Motta et al., 1997: fig. 4), indicating a link between the activity of these muscles and the movement of water and food into the mouth. Similar activity of the clavobranchialis musculature has not been examined in sarcopterygians (extant lungfish) nor in actinopterygians
(Lauder, 1979, 1982, 1983a, b; Bemis \& Lauder, 1986). Nevertheless, among fossil sarcopterygians, a variety of fossil lungfish possess well developed muscle attachment surfaces on the postbranchial laminae of the pectoral girdle. Comparable attachment surfaces occur on the clavicles of the rhizodont sarcopterygian fish Strepsodus. These surfaces may indicate the presence of a clavobranchiales comparable to various actinopterygians (Jessen, 1972), and the size of the depression in lungfish such as Griphognathus indicates that the muscles themselves could be of substantial size.

As described below, the action of ventral gill arch depressors may have improved both feeding and respiratory efficiency by increasing the rate at which water/food/air is brought into the oral cavity in chondrichthyans, sarcopterygians and actinopterygians, and particularly in phylogenetically basal taxa of the latter two groups. Evidence for the presence of these muscles and active branchial arch depression can also be found in certain fossil gnathostomes such as the Placodermi, suggesting the action of this gill arch musculature in feeding and respiration occurs throughout jawed fishes. By comparison, the action of the sternohyoideus muscle in lowering the mandible and opening the mouth via the hyoid arch and mandibulohyoid ligament, described as a feature of the Gnathostomata (e.g., Lauder, 1980, 1982), does not occur in chondrichthyans (Wilga et al., 2000), nor in placoderms (Johanson, in press). In these taxa the coracomandibularis, inserting at the jaw symphysis, opens the mouth.

\section{Materials and methods}

Specimens illustrated were either photographed after being coated with an ammonium chloride sublimate (Figs $3,4,5$ ) or scanned in from various publications (Figs 1, 2, 7). Line drawings (Fig. 6) were made directly from photographs. In Figure 8, a 25 $\mathrm{cm}$ long individual of the lungfish Neoceratodus was cut by hand into sections and photographed on a light table. Institutional abbreviations: AMF: Australian Museum, Sydney; QMF: Queensland Museum, Brisbane. 
The dermal pectoral girdle of fossil sarcoptery-gians and associated muscle attachments

The dermal pectoral girdle of fossil sarcopterygians is well known (e.g., Andrews \& Westoll, 1970a, b; Jarvik, 1972, 1980; Miles, 1977; Long, 1989; Fox et al., 1995; Lebedev, 1995; Ahlberg \& Johanson, 1997; Johanson \& Ahlberg, 1997). Among these, a variety of fossil lungfish including Sagenodus, Eoctenodus, Pillararhynchus, Holodipterus, Griphognathus, Chirodipterus and Ctenodus (Watson \& Gill, 1923; Miles, 1977; Long, 1987; Pridmore et al., 1994; Barwick \& Campbell, 1996; Campbell \& Barwick, 1999) possess a broad and well-developed postbranchial lamina associated with the cleithrum (cleith) and clavicle (clav), the main bones of the pectoral girdle. On this lamina (pbl), distinct depressions are visible, variable in size, depth and shape, but deepest laterally, where the lamina joins the external part of the cleithrum and clavicle (Figs 1-3). In Pillararhynchus, Holodipterus and Eoctenodus, this depression is represented by a small, shallow circle abutting the lateral margin of the lamina of the cleithrum (Fig. 1A, C, white arrow). There does not appear to be a corresponding depression on the postbranchial lamina of the clavicle. In other lungfish taxa, the depressions are deeper, are located on both the cleithrum and clavicle, and can contain narrow, bony processes within (Chirodipterus, Fig. 2A-C). These depressions appear to reach their maximum depth in Griphognathus (Fig. 1D). Among extant lungfishes, Neoceratodus also possesses a robust pectoral girdle and a relatively broad postbranchial lamina but lacks distinct depressions (Günther, 1871); the girdle and laminae are reduced as a whole in Protopterus and Lepidosiren, assigned to the family Lepidosirenidae (Bemis \& Lauder, 1986). Thus, no living lungfish would appear to possess these depressions on the postbranchial lamina of the pectoral girdle.

Comparable depressions on the dermal pectoral girdle are also unknown in most other, non-lungfish, sarcopterygian taxa, including coelacanths (Forey, 1981, 1998), onychodonts (Jessen, 1966) and members of the Dipnomorpha and Tetrapodomorpha (sensu Ahlberg (1991)). The Dipnomorpha includes taxa more closely related to lungfish than tetrapods, and includes the Porolepiformes, in which the lamina can be relatively wide with no indication of muscle attachments present (Jarvik, 1972). Youngolepis (Chang, 1991) is also assigned to the Dipnomorpha (Ahlberg, 1991) and its postbranchial lamina appears to be covered in dermal ornament (also the onychodont Strunius) rather than smooth. The Tetrapodomorpha include taxa more closely related to the Tetrapoda than the Dipnoi (lungfish) and generally possess reduced postbranchial lamina, often only represented by a narrow, unornamented strip along the dorsomedial margin of the cleithrum and clavicle (Jarvik, 1972, 1980; Fox et al., 1995; Lebedev, 1995). However, distinct depressions are associated with the unornamented postbranchial lamina on the clavicle of Strepsodus. Strepsodus is a member of the Rhizodontida, a group of tetrapodomorph fishes known primarily from teeth, scales, and the robust bones of the pectoral girdle (Andrews, 1973, 1985; Andrews \& Westoll, 1970b; Long, 1989; Jeffery, 2001; Johanson \& Ahlberg, 1998, 2001). New material of Strepsodus sp. from Queensland, Australia (Johanson et al., 2000) is disarticulated but relatively well preserved, including several clavicles (Figs 4, 5). These support a rounded depression of moderate size, located midway between the base of the ascending process (as.pr) and the anterior margin of the bone. The depth of this depression varies among the clavicles, but is deepest on QMF36954 and QMF36760 (Fig. 4A, B, att. clavo), where it is also surrounded by a distinct rim. The base of the depression is positioned relatively posteroventrally. In Figures 4 and 5, the clavicle is shown in life position, such that the ascending process of the clavicle (best preserved in QMF37408, Fig. 5A) overlaps the cleithrum posterodorsally (Fig. 6). In this position, the depression on the clavicle has a dorsal and anterior orientation (as indicated by the white arrows, Fig. 4C, D), becoming shallower and wider in this direction. The cleithrum lacks a comparable depression (Johanson et al., 2000).

Given these morphologies in Strepsodus and the various fossil lungfish, it seems reasonable to suggest that these depressions on the clavicle and/or cleithrum represent muscle attachments (e.g., as described for Sagenodus (Watson \& Gill, 1923)). -The deepest part of the depression represents the base of the attachment, with the muscle widening 


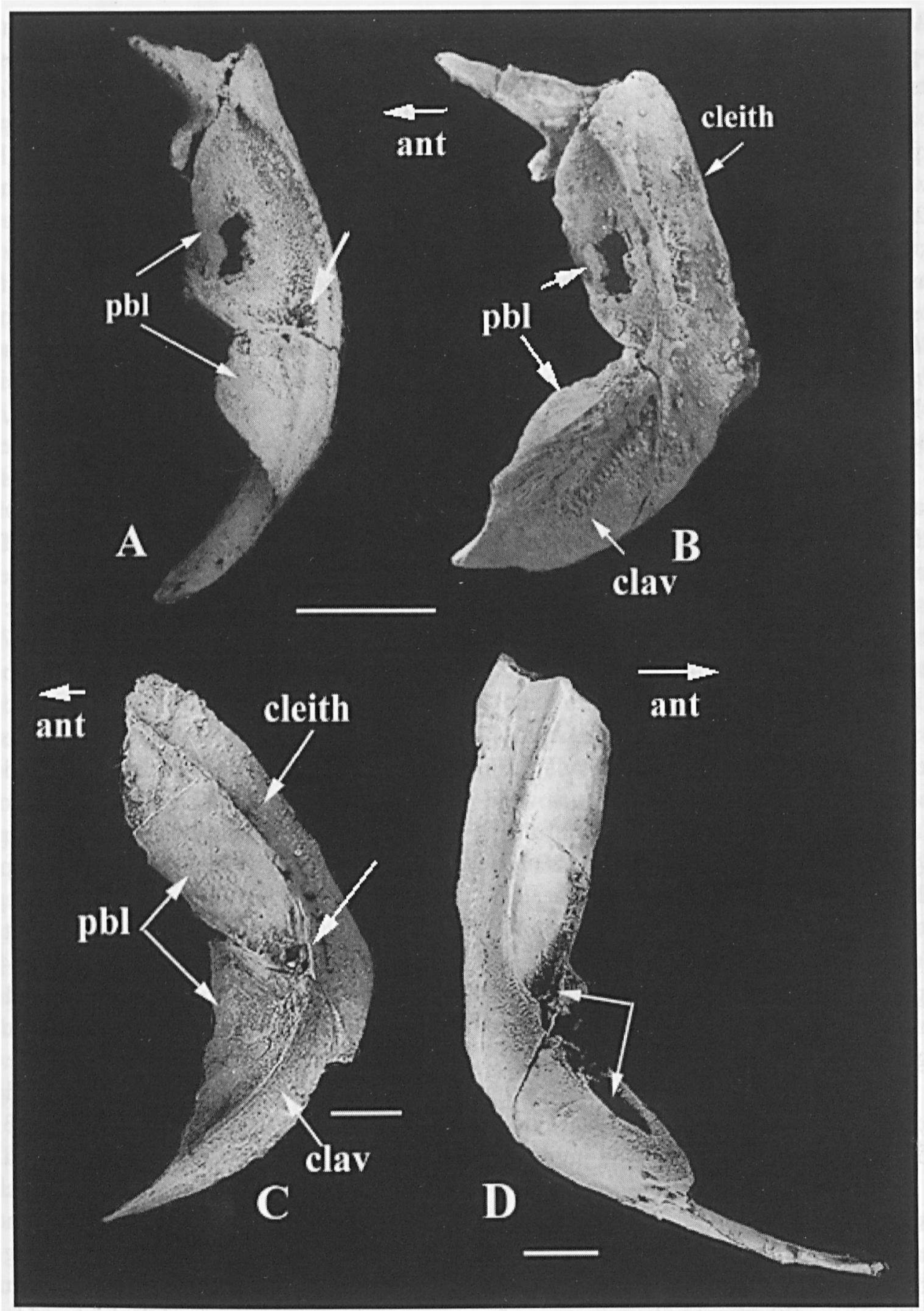

Fig. I. A-D, dermal pectoral girdles of fossil lungfish, cleithra and clavicles. A, B, Pillararhynchus longi WAM 86.9.595, A, anterior, $B$, lateral views showing postbranchial lamina and lateral depressions for attachment of clavobranchialis musculature (from Barwick \& Campbell, 1996). Scale $=1.0 \mathrm{~cm}$. C, Holodipterus meemannae (from Pridmore et al., 1994: fig. 82b). D, Griphognathus whitei ANU 49117, anterolateral view (from Campbell \& Barwick, 1999). Scale $=1.0 \mathrm{~cm}$. Arrows in A, C, D indicate depressions for muscle attachment. Abbreviations: clav, clavicle; cleith, cleithrum; pbl, postbranchial lamina. Images in Fig. 1A, B used with permission of Schweizerbart-Publishers, Stuttgart (Paleontographica A). Image in Fig. 1C from Pridmore et al. (1994), "Morphology and phylogenetic position of the holodipteran dipnoans of the Upper Devonian Gogo Formation of northwestern Australia'. Phil. Trans. R. Soc. London $B$ 344: 105-164, used with permission of The Royal Society London, and Dr. Peter Pridmore. Images in Fig. 1D used with permission of Prof. Ken Campbell. 


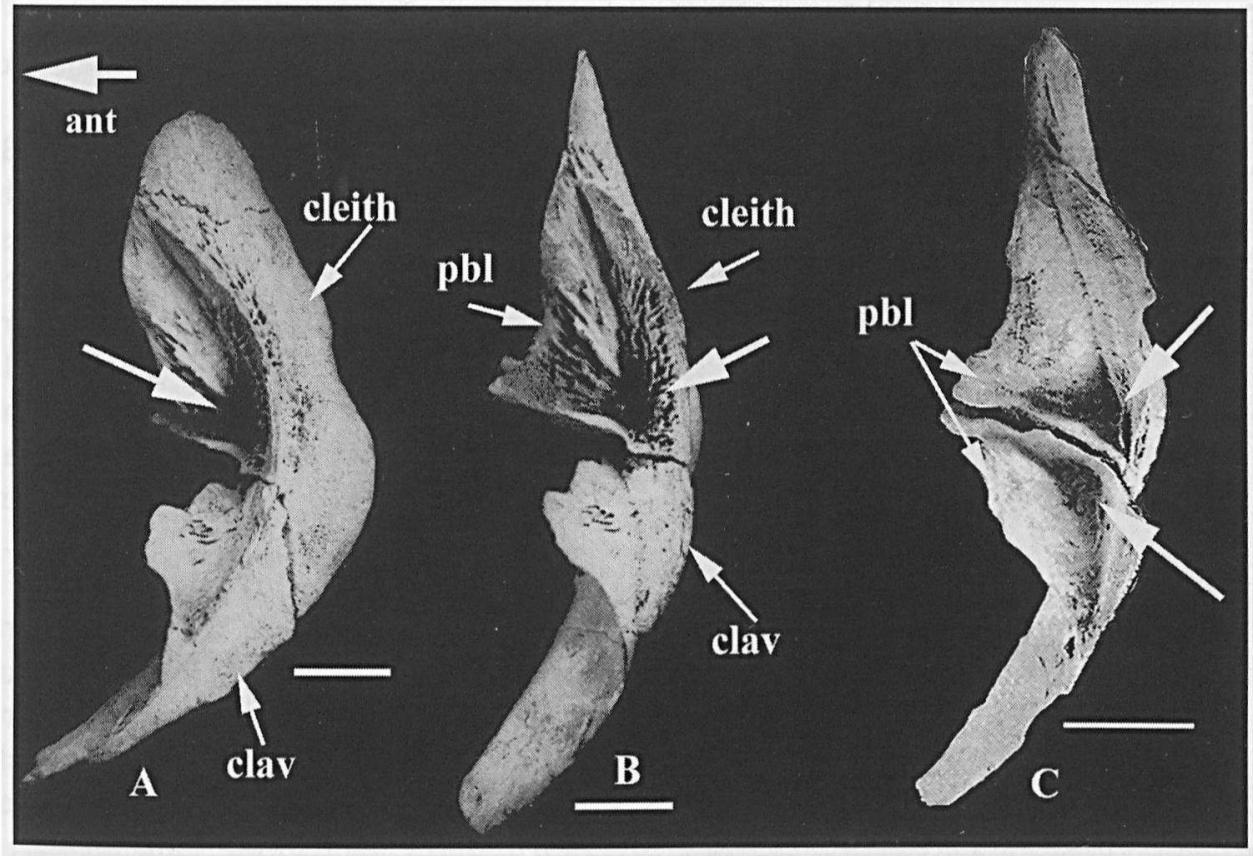

Fig. 2. A-C, dermal pectoral girdles of fossil lungfish, cleithra and clavicles. A-B, Chirodipterus äustralis, ANU35636, A, anterolateral, $\bar{B}$, anterior views showing postbranchial lamina and lateral depressions (large white arrows in A-C) for attachment of clavobranchialis musculature (from Campbell \& Barwick, 1999). Scale $=1.0 \mathrm{~cm}$. C, Chirodipterus australis, ANU49200 (from Campbell \& Barwick, 1999). Abbreviations in Figure 1, also oa.clav, overlap surface on the cleithrum for the clavicle. Images in Fig. $2 \mathrm{~A}-\mathrm{C}$ used with permission of Prof. Ken Campbell.

and possibly dividing into separate slips as it extends outwards from this base. On Strepsodus, the orientation of the muscle attachment is dorsal and anterior. In the case of the lungfish taxa, anterior views of the cleithra and clavicle indicate that the attachments would also appear to have a medial orientation because the deepest part of the attachment is laterally positioned (Figs 1A, B, 2). However, in Griphognathus (Fig. 1D) the depressions are extremely deep and oriented almost directly dorsoventrally, which may indicate a slightly different orienation relative to other lungfishes. The presence of depressions on both the cleithrum and clavicle may indicate the attachment of different muscles in these lungfish taxa, though the contiguous nature of the depressions/attachments (e.g., Figs $1,2)$ suggests these muscles had essentially similar functions, and were subsets of the same muscle group. On Holodipterus, Pillararhynchus, Eocteno$d u s$ and also Strepsodus, it appears that a single nuscle mass was present, attached to the cleithrum and clavicle, respectively (Long, 1987; Figs 1A-C,
$4,5)$. Overall, the muscle attachments on the cleithrum and/or clavicle of both the lungfishes and Strepsodus would have been located medial to the opercular and subopercular bones and the muscles themselves oriented anteriorly, dorsally, and also medially into the gill chamber.

In extant actinopterygians, the clavobranchialis musculature originates dorsally on the anterolateral surface of the cleithrum, on the smooth or unornamented portion representing the postbranchial lamina (Jessen, 1972; Jollie, 1982; Lauder \& Liem, 1983; Fig. 7, clavo), and inserts on the ventral surface of the ceratobranchial(s). This dorsal and lateral attachment on the dermal pectoral girdle seems to compare closely with the location of the depressions on the cleithra and clavicles of Strepsodus, Chirodipterus, Holodipterus, Griphognathus and Pillararhynchus, as described above. The anterodorsal orientation of these pectoral girdle depressions and the actinopterygian clavobranchiales are also very similar, that is, towards the branchial arch chamber. However, in extant lungfishes, the clavo- 


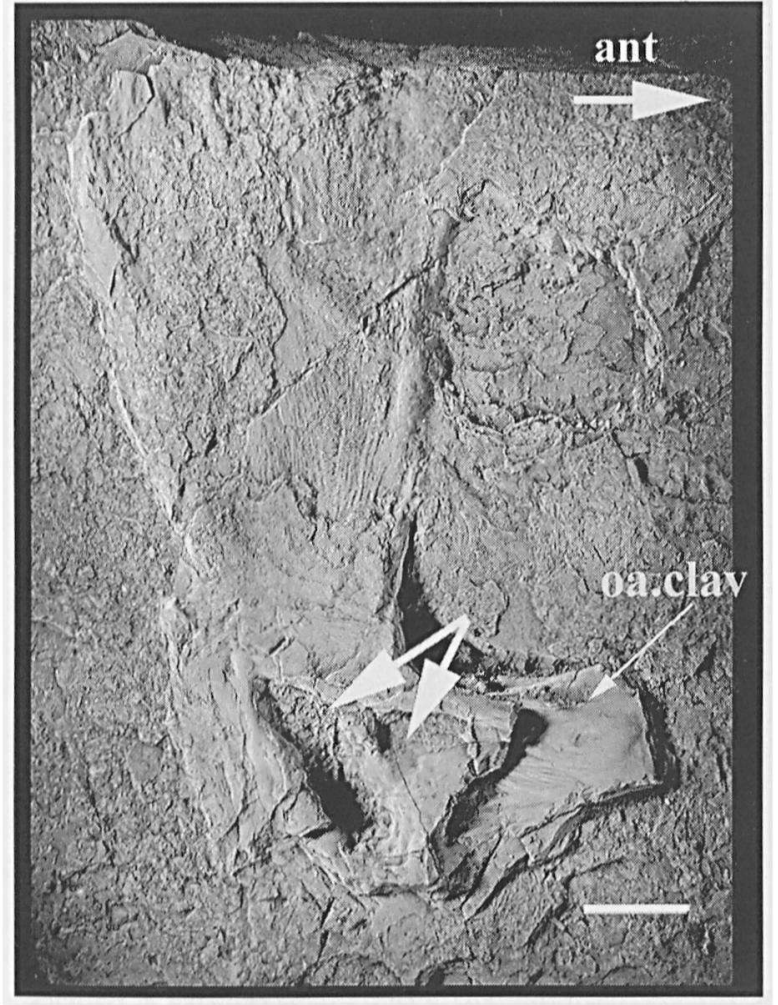

Fig. 3. Sagenodus AMF 6285, anterolateral view of cleithrum, larger arrows indicate depression for clavobranchiales. Scale $=$ $1.0 \mathrm{~cm}$.

branchiales musculature was said to originate on the 'inner and ventral edges' of the pectoral girdle (Edgeworth, 1926; Wiley, 1979; Jollie, 1982). Five clavobranchiales are present, with the anterior four slips arising from a single origin and the fifth from a second origin just posterior to the first (Edgeworth, 1926). Transverse sections cut through an individual of Neoceratodus (approximately $25 \mathrm{~cm}$ long) con-1 firm the relatively ventral and internal origin of these muscles (Fig. 8). In Figure 8, section $A$ is the more anterior. The dorsal portions of the branchial arches are fused to the braincase, while the ventral hang down into the gill chamber. Arches 2-5 are visible in this section, with the fifth being the smallest, and nearly hidden from view. The pectoral girdle can be seen on either side of the section, extending ventrally and medially towards the observer. Although cut, the curvature of the preserved girdle halves (which eventually meet in the midline) suggests the anterior parts of the girdle are visible in section A. The clavobranchiales muscle (clavo) preserved in section A originates from the ventromedial edge of this anterior part of the pectoral girdle and runs dorsomedially to the ventral portions of the branchial arches. Section B (Fig. 8B) is located just posterior to section $A$ and shows that the pectoral girdle is becoming thicker and is extending posterodorsally. This section of the pectoral girdle represents the cleithrum, while the girdle in section A represents the clavicle. The gill arches are visible in section $B$, but there are no muscles running from the pectoral girdle to the base of these arches. The muscles in this region are strictly transverse, and oriented towards the midline. Therefore, the clavobranchiales in Neoceratodus are largely restricted to the anterior and ventral portions of the pectoral girdle, as suggested by Edgeworth (1926). This differs from the fossil lungfish described above, in which the depressions for muscle attachment were more dorsolaterally located (comparable to the portion of the pectoral girdle shown in Fig. 8B). These differences may be related to a reduction in the size of the gill arches in extant lungfish; although these arches are large in Neoceratodus (e.g., Bemis, 1987), they are reduced relative to the size of those in taxa such as Griphognathus, particularly the posterior arches (e.g, compare Campbell \& Barwick, 1987: fig. 22, 1999 and Bemis, 1987: fig. 3B).

Another possibility, given the position and orientation of the muscle attachments, is that the muscles attaching to the pectoral girdle in Strepsodus and the fossil lungfish described above were associated with the operculum. However, the opercular and subopercular bones are moved by muscles originating dorsally on the endocranium (dilator operculi, adductor operculi, levator operculi, e.g., Jarvik, 1980: 95, 96). They are not likely to be muscles associated with the pectoral fin, as these generally originate on the scapulocoracoid rather than on the anterior parts of the pectoral girdle, and are oriented posteriorly to reach the fin, rather than anterodorsally (e.g., Andrews \& Westoll, 1970a: figs 31, 32; Janvier, 1980; Janvier \& Marcoux, 1976; Fox et al., 1995). Other muscles associated with the gill arches (e.g., transversi ventrales) run between the different elements of the arches themselves, and function to constrict or contract these elements rather than depress them (Wiley, 1979; Jollie, 1982). The sternohyoideus and coracomandibularis muscles run from the jaw symphysis or 


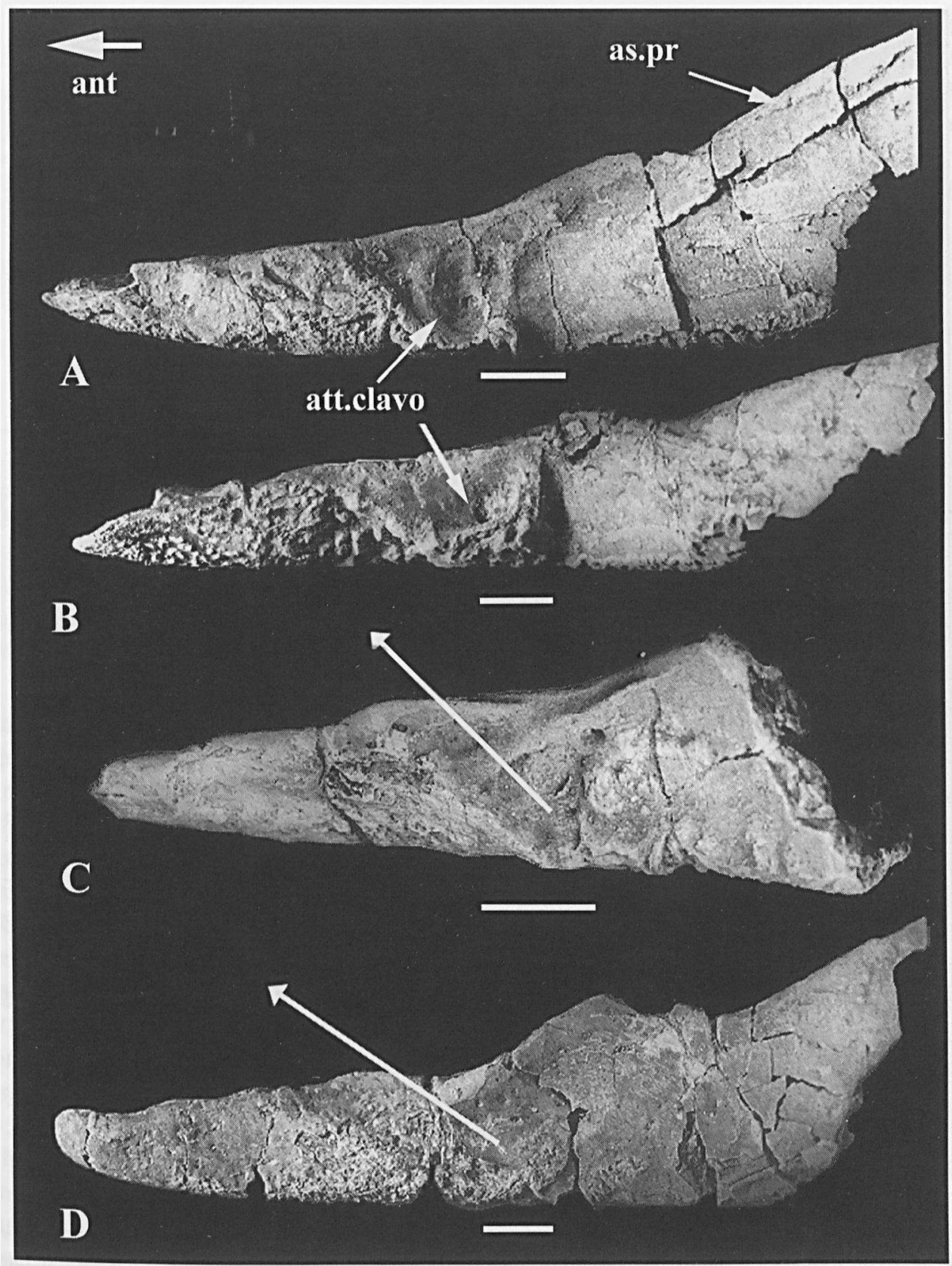

Fig. 4. Clavicles of Strepsodus sp. from the Lower Carboniferous Ducabrook Formation, central Queensland, Australia. External view of left clavicles, arrow indicates orientation of clavobranchialis muscle. A, QMF36760; B, QMF36954; C, QMF34606; D, QMF34608. Scale bar $=1 \mathrm{~cm}$. Abbreviations: ant, anterior; as.pr, ascending process of clavicle overlapping onto cleithrum; att.clav, depression marking the attachment surface for the clavobranchialis musculature. White arrows in Figure 4C, D indicate suggested orientation of the clavobranchiales, anterodorsally into the gill chamber.

hyoid arch to the pectoral girdle, but are ventral midline muscles (e.g., Bemis \& Lauder, 1986), and do not originate dorsally or laterally on the pectoral girdle.
Thus, it is difficult to come to any other conclusion as to the identity of the muscles attaching to the lateral depressions on the pectoral girdle of various fossil lungfishes and the rhizodont Strepso- 




Fig. 5. Clavicles of Strepsodus sp. from the Lower Carboniferous Ducabrook Formation, central Queensland, Australia. A, C, external view of right clavicle, B, external view of left clavicle. A, QMF37408; B, QMF37536, arrow indicates orientation of clavobranchialis muscle; C, QMF37566. Scale bar $=1 \mathrm{~cm}$, except for B, C, where scale bar $=0.5 \mathrm{~cm}$. Abbreviations as in Figure 4 .

dus. By comparison to extant actinopterygians (e.g., Fig. 7), these depressions indicate the point of attachment (origin) of the clavobranchiales muscles. In Strepsodus, the presence of a single muscle is indicated, as in the actinopterygians. In fossil lungfish such as Griphognathus and Chirodipterus, depressions on both the cleithrum and clavicle indicate two separate origins for the clavobranchiales mus- culature, as described above for the extant lungfishes (first four slips anteriorly on the clavicle and the fifth posteriorly on the cleithrum). Holodipterus, Pillararhynchus and Eoctenodus may have resembled the condition in Strepsodus and the extant actinopterygians illustrated in Fig. 7, with a single muscle origin on the cleithrum (Fig. 1). This muscle could have comprised several slips as in Neoceratodus, 


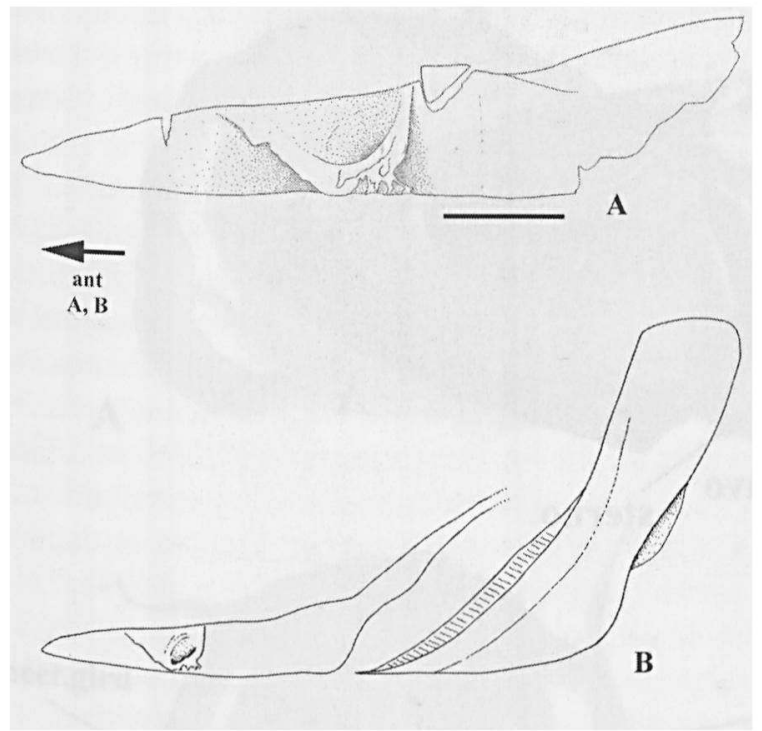

Fig. 6. A, B, QMF36954, line drawing. B, reconstruction of clavicle of Strepsodus sp. (based on QMF36954 and QMF37408) and its relationship to the rhizodont cleithrum (e.g., Long, 1989)).

but a separation into anterior and posterior muscle masses appears not to have occurred. Branchial arches are not well preserved in fossil lungfishes, but in Griphognathus, all arches are large and well tormed, from anterior to posterior, with no substantial decrease in size posteriorly (Miles, 1977; Campbell \& Barwick, 1987: figs 21, 22). Branchial arches (ceratobranchials) are also known for Chirodipterus and Holodipterus (Miles, 1977), where again, they appear relatively well developed, although a complete set of arches, comparable to Griphognathus, is not preserved. As described above, the muscle depressions for the attachment of the clavobranchiales in Chirodipterus are large, occur on both bones of the pectoral girdle, and may have held bony splints for additional muscle attachment. The muscle attachment on the pectoral girdle of Holodipterus is much smaller by comparison, and one could predict that a set of gill arches similar to Griphognathus was present in Chirodipterus, with some reduction of these in Holodipterus. However, a tull set of arches would be needed to test this suggestion. It is also somewhat difficult to make generalisations as to gill arch size and the corresponding size of the clavobranchiales; in Neocerato$d u s$, the postbranchial lamina associated with the cleithrum and clavicle is well-developed, but mus- cle attachments comparable to those described above for the fossil forms are lacking (Günther, 1871; Jarvik, 1980; pers. obs.). Nevertheless, anterior and posterior clavobranchiales are present, attaching to all five gill arches, although the latter arches are relatively reduced in size (Edgeworth, 1926; Wiley, 1979; Bemis, 1987).

The above discussion focused on previously undescribed (fossil lungfish) and new (Strepsodus) features on the dermal pectoral girdle indicating the origin or attachment of muscles; these were identified as the clavobranchiales by comparison to extant actinopterygians. Interpreting the phylogenetic significance of this character distribution is more problematic, since evidence for the attachment of this musculature in the form of pits or depressions is absent from the postbranchial lamina of most fossil sarcopterygian taxa (Jessen, 1966; Jarvik, 1972, 1980; Forey, 1981, Fox et al., 1995; Lebedev, 1995). Most of these taxa have smooth, if reduced, postbranchial laminae, but in other taxa, the laminae are covered in ornamentation, precluding any possibility of muscle attachment. The latter include the onychodont Strunius (Jessen, 1966) and the dipnomorph Youngolepis (Chang, 1991), as well as phylogenetically basal actinopterygians such as Mimia (pers. obs. AMF119672) and Dialipina (Schultze \& Cuumba, 2001).

The available evidence suggests that a dorsolateral origin of the clavobranchialis musculature on the pectoral girdle occurs in tetrapodomorph and dipnomorph sarcopterygians (Strepsodus and fossil lungfish, respectively) and actinopterygians (Jessen, 1972). In chondrichthyans, by comparison, the gill arch depressing coracobranchiales muscles originate in the midline, ventrally on the coracoarcualis muscle (which extends anteriorly from the ventral part of the coracoid (e.g., Motta \& Wilga, 1999)). Although this evidence is incomplete, it distinguishes osteichthyans (sarcopterygians and actinopterygians) from chondrichthyans. Actinopterygian taxa such the extant genus Acipenser have a wide postbranchial lamina, but the clavobranchiales bypass this surface altogether to insert on the scapulocoracoid (Jessen, 1972: pl. 5), which may also be the case for the sarcopterygians and actinopterygians lacking evidence for the attachment of the clavobranchiales on the dermal pectoral girdle. This could 

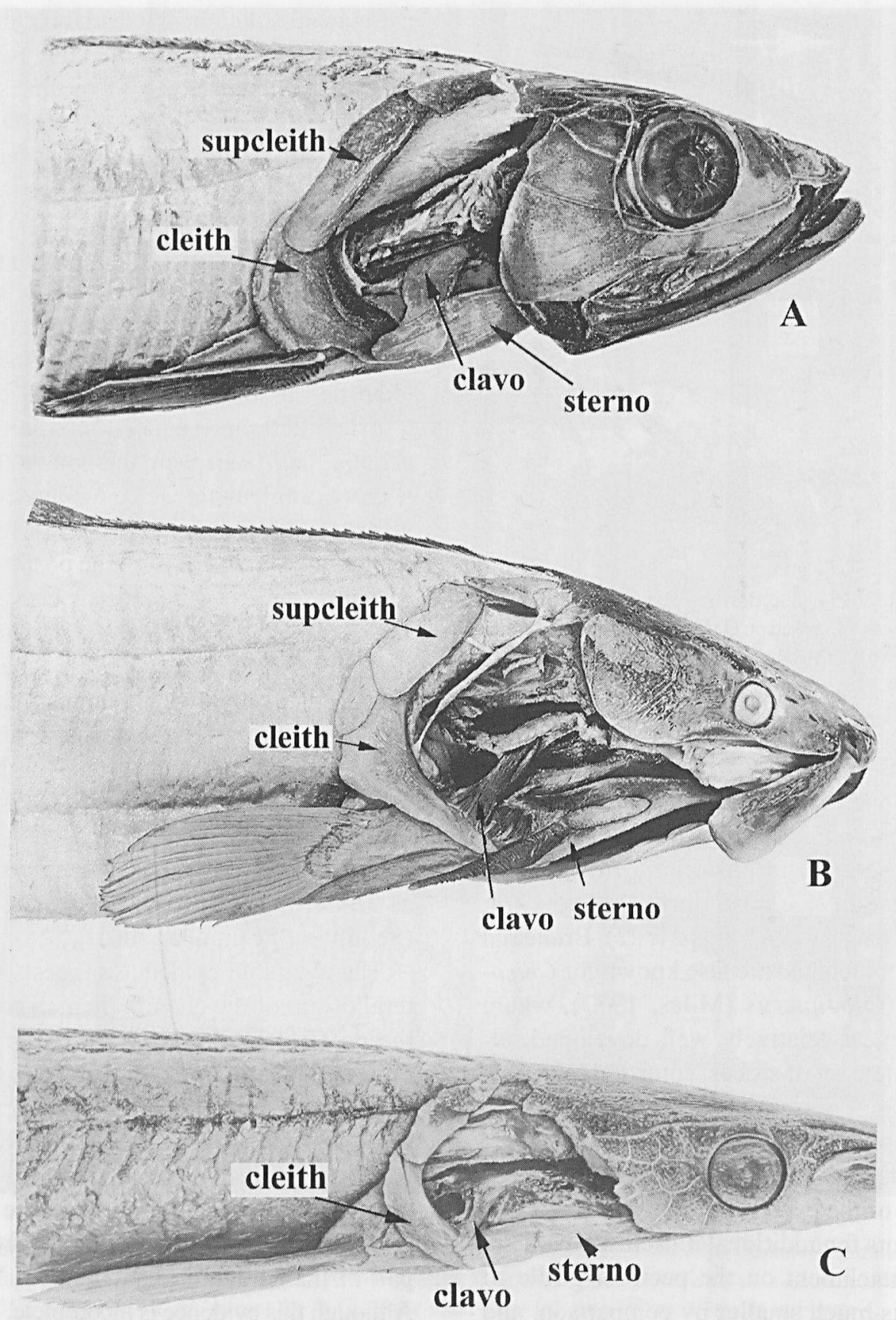

Fig. 7. Actinopterygian gill arch musculature, lateral view of cleithrum and muscles, including clavobranchiales (clavo) passing into gill chamber (adapted from Jessen, 1972: figs 7.3, 8.3, 9.3). A, Elops saurus. B, Amia calva. C, Lepisosteus osseus. Images used with permission of Taylor \& Francis (Fossils and Strata).

still be considered a dorsal origin relative to the condition in chondrichthyans, where the coracobranchiales are restricted to a ventral and midline origin.
The fossil jawed fish group Placodermi is generally resolved phylogenetically to the base of the clade Gnathostomata (Janvier, 1996, 2001). Among placoderms, certain taxa possess depressions on the 


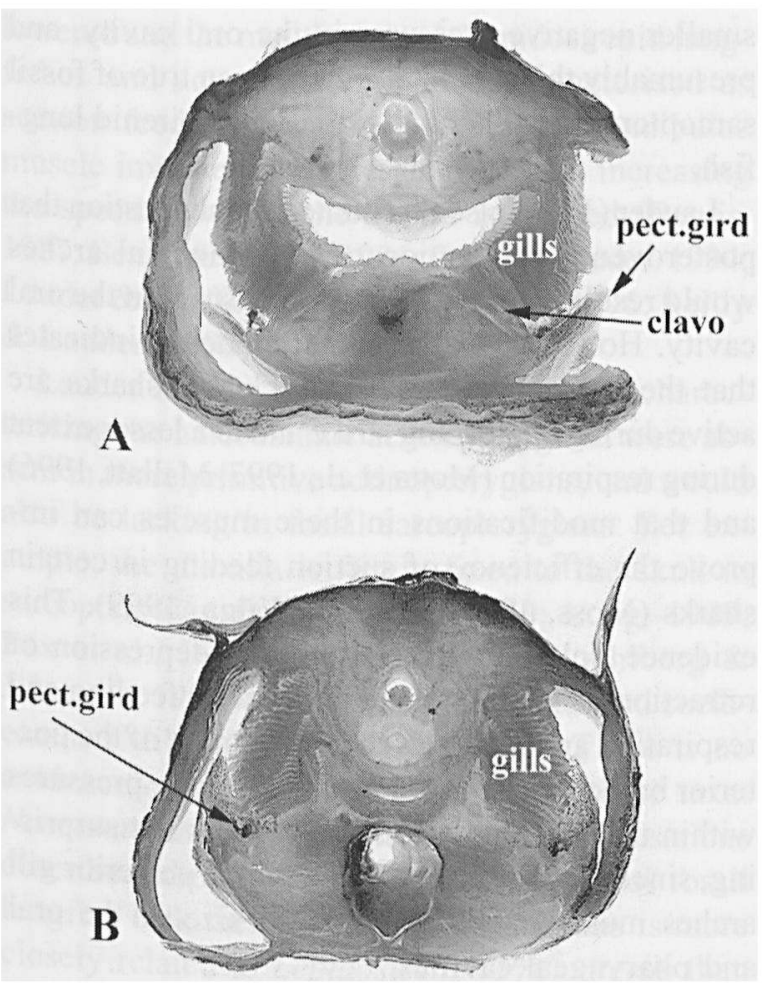

Fig. 8. A, B, transverse sections (hand cut) through the gill chamber of Neoceratodus forsteri (individual approximately 25 cm long). Abbreviations: gills, gill arches; clavo, clavobranciales muscle; pect.gird, pectoral girdle.

anterolateral margins of the trunkshield comparable in position to those on the postbranchial laminae of Strepsodus and the fossil lungfish described above and to the position of the clavobranchiales muscle in extant actinopterygians (Heintz, 1932, 1934; Miles, 1971; Goujet, 1975; Dennis \& Miles, 1979a, 1979b; Johanson, in press). These depressions appear to only characterise the derived placoderm group Arthrodira (Goujet, 2001), and it is suggested this group may have possessed a clavobranchiales musculature depressing the branchial arches. In other placoderm taxa, these depressions are absent; as well, the trunkshield covered the scapulocoracoid laterally and anteriorly, so that a dorsolateral muscle attachment on the scapulocoracoid (comparable to the suggested position for the sarcopterygians and actinopterygians described above) would have been impossible. In these placoderm taxa, the ventral gill arch depressors may have been more comparable to the chondrichthyan coraco- branchiales, attaching to a ventral midline muscle like the chondrichthyan coracoarcuales.

Given these observations, it is interesting to consider the pectoral girdle of the sarcopterygian (or basal osteichthyan) Psarolepis (Zhu et al., 1999; Zhu \& Schultze, 2001). This pectoral girdle shows an extra bone comparable in relative position to the spinal plate of the placoderm trunkshield. The postbranchial lamina of the Psarolepis pectoral girdle is covered in ornament (Zhu et al., 1999: fig. 2), and no muscle attachment surfaces are visible on this lamina. Furthermore, the scapulocoracoid is flat, and closely attached to the internal surface of the girdle, very similar to the condition in a variety of placoderms (e.g., Stensiö, 1959; Ørvig, 1975; Young, 1980). The scapulocoracoid in Psarolepis may have been largely hidden behind the pectoral girdle, preventing attachment of a clavobranchiales musculature, and the ventral gill arch depressors may have also been more comparable to the chondrichthyan coracobranchiales. Thus, although there is a broad, potentially phylogenetically meaningful distribution regarding the origin of the ventral gill arch depressing musculature in osteichthyans and chondrichthyans, much evidence is lacking from fossil taxa in the former group, and Psarolepis may show an chondrichthyan-type muscle origin. As well, the origins characterising both of these groups would appear to be present in the fossil group Placodermi.

\section{The role of the clavobranchialis in feeding and respiration}

Initial stages in feeding and respiration involve bringing aerated water/air/food into the mouth or oral cavity. The generalised osteichthyan (Sarcopterygii + Actinopterygii) mechanism by which this occurs includes a lowering of the mandible via the mandibulohyoid ligament through the posteroventral depression of the hyoid (by the sternohyoideus muscle; Lauder, 1980, 1982, 1983a, 1985; Bemis \& Lauder, 1986). Depression of the hyoid results in a posterodorsal movement of the dorsal part of the ceratohyal, transmitted through the mandibulohyoid ligament to the rear of the jaw, which is rotated around the quadrate-articular joint. These actions open the mouth and expand the oral cavity, creat- 
ing a negative pressure within (suction) which in turn results in the flow of water (or air) and food into the mouth. Chondrichthyans possess a mandibulohyoid ligament, but electromyographic and manipulation experiments have indicated that the action of the ligament is decoupled from that of the coracohyoideus ( $\because$ the sternohyoideus; Wilga et al., 2000). Instead, the chondrichthyan mandible is depressed by the action of the coracomandibularis muscle. All of these muscles involved in depressing the mandible and/or the hyoid arch are part of the hypobranchial musculature, originating on the pectoral girdle near the midline, on the hypaxial musculature or on the pericardium surrounding the heart (Daniel, 1934; Jessen, 1972; Bemis \& Lauder, 1986; Motta \& Wilga, 1995; Wilga \& Motta, 1998).

The focus of this discussion is on the mechanics of actively drawing air/water/food into the oral cavity during feeding and respiration. Generally, studies on this aspect of respiration and feeding have concentrated on the actions of the main hypobranchial muscles opening the mouth and expanding the oral cavity, but have said little about possible contributions of the clavobranchiales (bony fishes) or coracobranchiales (in chondrichthyans) attaching to and depressing the ventral gill arches. One reason for this may be that the clavobranchiales ( $=$ pharygnoclavicularis externus and internus (Jollie, 1982)) function in food manipulation in the Euteleostei, a large, phylogenetically derived actinopterygian group characterised by sizeable denticulated plates on the last branchial arch (to which the clavobranchiales attach (Liem, 1970; Lauder \& Liem, 1981; Lauder, 1983)). Additionally, several of these studies have investigated morphological specialisations designed to increase the efficiency of mouth expansion and suction of food, air or aerated water into the oral cavity. These specialisations characterise derived actinopterygians (Alexander, 1969, 1970; Liem, 1970, 1980; Lauder, 1980, 1982; Lauder \& Liem, 1983), lepidosireníd lungfish (Protopterus + Lepidosiren; Bemis, 1987; Bemis \& Lauder, 1986; Campbell \& Barwick, 1988b), tetrapods (Schaffer \& Lauder, 1985), and certain sharks (Moss, 1977; Motta \& Wilga, 1999). Lauder (1980: 315) suggested that plesiomorphic actinopterygians lacking these specialised features would have generated smaller negative pressures in the oral cavity, and presumably this would also have been true of fossil sarcopterygians, including non-lepidosirenid lungfish.

Lauder (1980) also discounted the suggestion that posteroventral retraction of the branchial arches would result in larger negative pressures in the oral cavity. However, experimental evidence indicates that the coracobranchiales muscles of sharks are active during the feeding strike and to a lesser extent during respiration (Motta et al., 1997; Mallatt, 1996) and that modifications in these muscles can improve the efficiency of suction feeding in certain sharks (Moss, 1977; Motta \& Wilga, 1999). This evidence links muscle activity and depression or retraction of the branchial arches with feeding and respiration and indicates that movement of the posterior branchial arches increases negative pressures within the oral cavity. This is perhaps not surprising, since retracting or depressing the posterior gill arches must increase the overall size of the oral and pharyngeal cavities.

For example, halecostome actinopterygians, including Amia and teleost fishes, are able to protrude the maxilla (Lauder, 1980, 1982, 1985; Liem, 1980; Lauder \& Liem, 1983), creating a rounder and more elongate, tube-like mouth opening, and increasing the rate of flow of water into the mouth. Extant lungfishes such as Lepidosiren possess complex overlapping and interlocking upper and lower lips (absent in Neoceratodus; Bemis, 1987: 263) which narrow the gape of the mouth to achieve the same effect and prevent water from escaping laterally (Lauder, 1985: fig. 12.6). A variety of fossil lungfish have large lips and could have narrowed the mouth opening (Campbell \& Barwick, 1987, 1988b; Barwick \& Campbell, 1996), but there is no evidence that these interlocked as in Lepidosiren. Additionally in halecostome actinopterygians, a second jaw-lowering mechanism acts through the opercular series of bones and the retraction of the levator operculi (Alexander, 1969; Liem, 1970, 1980; Lauder, 1980). Here, the interopercular bone (absent in non-halecostome actinopterygians) transmits the movement of the levator operculi through to the mandible. This acts alongside the jaw mechanism acting through the mandibulohyoid ligament and increases the speed at which the mandible is 
lowered and the mouth opened. Lepidosirenid lungfishes and aquatic amphibians (characterised as suction feeders) possess a depressor mandibulae muscle involved in depressing the jaw, increasing the speed at which the mouth is: opened (Bemis, 1987; Bemis \& Lauder, 1986; Gillis \& Lauder, 1994; Lauder \& Shaffer, 1985; Reilly, 1995, 1996; Reilly \& Lauder, 1990).

Lauder (1980) noted that the features characterising the halecostome actinopterygians were absent in more primitive actinopterygians, and would also be lacking in fossil sarcopterygians. For example, the maxilla is firmly fixed to the skull in sarcopterygian fishes (Jarvik, 1980; Long, 1989; Fox et al., 1995; Long et al, 1997; Ahlberg \& Johanson, 1997) and absent in lungfishes and coelacanths (Miles, 1977; Janvier, 1996). There is no evidence of an interopercular bone in these taxa. Neoceratodus lacks the lepidosirenid specialisations described above, and it is likely that most fossil lungfish lack them as well (Neoceratodus is more closely related to Lepidosiren + Protopterus than to most fossil lungfish (e.g., Schultze \& Marshall, 1993)). In terms of the ram-suction feeding index, plesiomorphic actinopterygians and fossil sarcopterygians (including non-lepidosirenid lungfishes) would be placed nearer to ram feeding end of the spectrum, reflecting the absence of morphological specialisations of the skull, jaws or musculature and their reduced ability to generate negative pressures in the oral cavity.

Because jaw-lowering muscles such as the sternohyoideus and coracohyoideus originate in association with the pectoral girdle, an additional feature influencing the speed of mouth opening is the degree to which the pectoral girdle is retracted by the hypaxial musculature (Lauder, 1985; Campbell \& Barwick, 1988b). In plesiomorphic actinopterygians and fossil sarcopterygians, the pectoral girdle is large, and attached to the dorsal roof of the skull via a succession of bones (Jessen, 1972; Jarvik, 1980; Lauder, 1980; Lauder \& Liem, 1983;'Gardiner, 1984; Johanson \& Ahlberg, 1997; Fig. 7). This is also the case in fossil lungfishes, where the girdle is stout (e.g., Figs' 1-3) and joined to the dorsal skull roof via a well-developed anocleithrum (Schultze, 1977, 1987; Jarvik, 1980; Barwick \& Campbell, 1996; Schultze \& Chorn, 1998). In these taxa, the effects of the posterior retraction by the hypaxial musculature would be offset by the size of the pectoral girdle and its solid attachment to the skull.

In the lepidosirenid lungfish (Lepidosiren + Protopterus), the pectoral girdle is substantially reduced in size, and potentially more readily retracted $(\mathrm{Be}-$ mis, 1987). Additionally, the anocleithrum is absent (Owen, 1841; Bishop \& Foxon, 1968; McMahon, 1969; Bemis, 1987), and the pectoral girdle, freed from its connection to the skull, is stabilised during retraction by muscular attachment to the cranial rib (Bishop \& Foxon, 1968; Bemis, 1987). Craníal ribs, articulating to the occipital region of the skull, also occur in Neoceratodus (Günther, 1871) and have been recognised in a variety of fossil lungfish (Schultze, 1975; Long, 1993; Ahlberg et al., 2001). However, only in lepidosirenids are the cranial ribs substantially larger than the pleural trunk ribs, and they articulate to the rear of the chondrocranium via a moveable synovial articulation (Bemis, 1987). The cranial rib is more similar in size to other ribs in Neoceratodus and the fossil taxa, and the synovial articulation is absent (Günther, 1871; Miles, 1977; Bemis, 1987). As well, Neoceratodus retains an anocleithrum, joining the pectoral girdle to the skull (Günther, 1871), as in the fossil lungfish taxa.

The pectoral girdle would therefore be a very mobile unit in lepidosirenids, particularly compared to Neoceratodus and other lungfish. When retracted by the hypaxial musculature, this mobility results in increased retraction (and speed of retraction) of the mandible and hyoid arch. This would lead to a more rapid oral expansion and a more rapid increase in the negative pressure in the oral cavity, whether these lungfishes are feeding (Lauder, 1985) or respiring by gulping air (Bishop \& Foxon, 1968; Campbell \& Barwick, 1988b). This mobile pectoral girdle would appear to be another lepidosirenid speciality that is not as well developed or even absent (e.g., interlocking lips, depressor mandibulae) from other lungfish taxa, including Neoceratodus.

Thus, there are a variety of morphological specialisations shown by fishes to increase the rate at which water/food/air enters their mouth during the retraction of the hyoid arch and mandible. Fossil sarcopterygians (including fossil lungfish and to some degree, Neoceratodus) as well as plesiomorphic and fossil actinopterygians would generally 
appear to lack these specialisations. Nevertheless, the ability to enhance suction forces within the oral cavities beyond those generated by depression of the lower jaw in these taxa should not be discounted; in this regard, the clavobranchialis has received little attention. For example, Lauder (1980: 315) did not believe that retraction of the branchial arches would result in a large negative pressure in the oral cavity. However, he also noted that all branchial muscles were active during the first two feeding phases of initial strike and oral manipulation, where the initial strike involved bringing the food item into the oral cavity (Lauder, 1983a: 28). This is comparable to data from extant sharks indicating that the coracobranchialis muscles were active and moving the ventral gill arches during feeding (Motta et al., 1997: fig. 4) and respiration (Mallatt, 1996).

By retracting the ventral gill arch elements, the clavobranchial and coracobranchial muscles expand the branchial basket and increase the size of the oropharyngeal cavity. The action of these muscles supplements oral expansion caused by mandibular depression and most importantly, would appear to occur at the same time as mandibular depression, the main activity bringing water/food/air into the oral cavity. The action of the clavobranchial and coracobranchial musculature does not rival the sternohyoideus/coracohyoideus in expanding the oral cavity in osteichthyans, but may have served to supplement this expansion in taxa lacking morphological features improving the efficiency of water/ air/food flow into the mouth. The distinct muscular attachments on the dermal pectoral girdle described above in Strepsodus and in lungfishes such as Griphognathus and Chirodipterus indicate that this was a noticeably large muscle(s), occupying the postbranchial laminae of both the cleithrum and clavicle in the latter two taxa. It does not seem likely that these clavobranchiales functioned generally in food processing in lungfishes in the manner described for euteleostean actinopterygians, where the last branchial arch carries opposing tooth plates dorsally and ventrally (e.g., Liem, 1970; Lauder, 1983a). Denticulated plates do occur on the branchial arches of Griphognathus and (Miles, 1977; Campbell \& Barwick, 1987, 1999), but these appear to be largely restricted to the midline basibranchials. A plate was also said to be present on a basihyal or basibranchial of a species of Holodipterus (Pridmore et al., 1994), but it lacks denticles entirely (Campbell \& Barwick, 1999: fig. 13C), and the muscle attachment for the clavobranchiales on the pectoral girdle was relatively small. By comparison, denticulated plates are absent in other taxa, including Chirodipterus, in which the clavobranchiales muscle attachments were quite large (Miles, 1977; Fig. 2). Among non-dipnoan sarcopterygians, denticulated plates are present on the branchial arches of Eusthenopteron (Jarvik, 1980), but are not clearly developed on other tetrapodomorphs (sensu Ahlberg (1991)) such as Gogonasus (Long et al., 1997: fig. 46) or Medoevia (Lebedev, 1995).

\section{Discussion}

The mandible of jawed fishes is lowered (and the mouth opened) either by the action of the sternohyoideus muscles (via the mandibulohyoid ligament and hyoid arch) in osteichthyans or by coracomandibularis muscles in chondrichthyans. Many taxa assigned to the fossil jawed fish group Placodermi lack attachment surfaces for the mandibulohyoid ligament on the lower jaw, or have these in a functionally inappropriate position. Thus, the placoderm jaw may have also been lowered by a coracomandibularis muscle inserting at the lower jaw symphysis (Wilga et al., 2000; Johanson, in press). With regards to mechanisms related to feeding and respiration, a more characteristic gnathostome feature may be the presence and action of the coracobranchiales and clavobranchiales muscles in depressing the branchial arches, expanding the buccopharyngeal cavity and increasing the suction within. The coracobranchiales and clavobranchiales muscles have a different innervation (Jollie, 1982) but both belong to the branchial musculature, while the sternohyoideus and coracomandibularis are hypobranchial muscles (Edgeworth, 1935; Miyake et al., 1992; Motta \& Wilga, 1995, 1999; Mallatt, 1996). Developmentally, both muscle groups derive from the paraxial mesoderm, the branchial from the more anterior unsegmented cranial paraxial mesoderm and the hypobranchial from the more posterior segmented somitic paraxial mesoderm (Schilling \& Kimmel, 1994, 1997; Hacker \& Guthrie, 1998). 
The presence of gill arch depressing muscles such as the clavobranchiales and coracobranchiales may be a synapomorphy for the jawed fishes as they would appear to be absent in jawless fishes. Branchial openings (and gill arches) are present in the fossil jawless fish groups Anaspida, Thelodonti, Osteostraci and Galeaspida, and in the latter two taxa, the position of the gill arches is clearly visible on the cartilaginous walls throughout the large oropharyngeal cavity (Janvier, 1996). In the Osteostraci, the pectoral girdle is anteriorly positioned, and is part of the headshield, while the scapulocoracoid supporting the fin is located on a lateral extension of the rear wall of the oropharyngeal cavity (Janvier, 2001). Any muscles depressing the osteostracan ventral gill arches in the manner of the clavobranchiales/coracobranchiales would have to attach to these posterior walls of the orobranchial cavity. These walls separated the oropharyngeal cavity from the trunk, precluding an attachment to the hypaxial musculature; as well, the heart was enclosed within this posterior wall (Janvier, 2001), impeding any attachment to the pericardium. However, sections through the osteostracan headshield indicate that the gill arches extended across the posterior walls of the oropharyngeal cavity, filling the entire cavity dorsally and ventrally, anteriorly and posteriorly, leaving no apparent room for muscle attachment (Stensiö, 1927: fig. 40). Intrabranchial muscles contracting the gill arches have been reconstructed in osteostracans (Janvier, 1985: figs 14B, 19B), and increases in the size of the oropharyngeal cavity may have depended on passive recoil of these muscles during expiration, as in extant lampreys (Randall, 1972).

The absence of muscles depressing the gill arches (and lower jaws) has been linked to functional and ecological scenarios involving active inspiration (ventilation) and increased predation or foraging associated with the evolution of jaws (Mallatt, 1996). However, these explanations may be inadequate. For example, it is somewhat surprising that osteostracans lack muscles actively expanding the oral/ oropharyngeal cavities; they had pectoral fins supported by moveable rays and an associated musculature, as well as an elongate trunk, dorsal fin(s), and a well-developed caudal fin (Janvier, 1996: fig. 4.14). In certain respects, osteostracans would ap- pear to have been more active swimmers than some jawed fishes, for example, various placoderms (such as the antiarch Remigolepis) with relatively short trunks and caudal fins, small pectoral fins and no dorsal fins (Janvier, 1996: fig. 4.53; Johanson, 1997). Ventral gill arch muscles comparable to the osteichthyan clavobranchialis and/or the chondrichthyan coracobranchialis would have been useful in feeding, and perhaps more importantly for a putatively active osteostracan, respiration. Alternative explanations for the absence of these muscles are described below, based on considerations of gill arch homology and gene expression in these arches in the lamprey, and how this may have influenced the development of the branchial musculature in jawless fishes, including fossil forms such as the osteostracans. As well, the possible influence of the anterior position of the pectoral fin in osteostracans on the branchial and hypobranchial musculature is discussed, based on recent evidence on muscle development from the paraxial mesoderm in extant animals such as chondrichthyans, zebrafish (Neyt et al., 2000) and amniote tetrapods (Dietrich et al, 1999; Hacker \& Guthrie).

For example, the absence of ventral gill arch depressors may relate to the homology of the gill arches between jawless and jawed fishes. In extant jawless fishes such as the lamprey, the arch itself is lateral to the gills, while in jawed fishes, the arch and its related blood and nerve supply are medial to the gill (Schaeffer \& Thomson, 1980; Janvier, 1996; Mallatt, 1996). In osteostracans, the gill arch is lateral relative to the gills, as in lampreys (Janvier, 1985). The lateral and medial positions of these branchial arches suggests these arches are not homologous and that the ventral gill arch musculature developed in jawed fishes in conjunction with the medial arches.

However, recent considerations of shared similarities in the development of lamprey and gnathostome branchial arches indicate that these are homologous (Kimmel et al., 2001). In both groups, neural crest (ultimately forming the branchial arch) extends ventrally to form a "shell' around a core of unsegmented cephalic mesoderm (forming the branchial musculature). In lampreys, the neural crest "shell" is restricted to the lateral side of the mesodermal core, forming the branchial arch in this 
position. In gnathostome evolution, this neural crest continues to migrate medially around the mesodermal core, and there forms the medial arch characteristic of the group. The basic patterning of the cephalic paraxial mesoderm and neural crest migration is similar in lampreys and jawed fishes, supporting branchial arch homology (Kimmel et al., 2001). These observations also suggest that the branchial musculature is homologous in both groups.

One important observation involves the development of a dorsal-ventral gradient in gene expression within the gill arches of jawed fishes (Miller et al., 2000; Kimmel et al., 2001; Neidert et al., 2001). This includes gradients in the neural crest derived tissues necessary for the development of the ventral cartilages of the branchial arches, as well as the joints between the dorsal and ventral cartilages (Kimmel et al., 2001). The dorsal-ventral gradient also influences the development of the branchial muscles from the cephalic paraxial mesoderm. The zebrafish sucker/endothelin 1 gene is restricted to the ventral parts of the branchial arch and mutations in this gene substantially reduce the ventral branchỉal muscles (Miller et al, 2000: fig. 7E-H; Kimmel et al., 2001), including muscles of the more posterior arches such as the transversus ventralis. This particular mutation also affects the ventral branchial arches themselves, though the hypobranchial muscles (e.g., the sternohyoideus) do not seem to be affected (Miller et al., 2000: fig. $7 \mathrm{E}, \mathrm{F})$.

A dorsal-ventral gradient in gene expression appears to be absent in lampreys (Kimmel et al., 2001; Neidert et al., 2001), correlated with the absence of separate dorsal and ventral arch components, and joints between these arches (Morrison et al., 2000). These latter observations focused on overlapping distributions of separate Dlx genes in gnathostomes; in lampreys these genes are expressed throughout the relevant neural crest prior to migration, with no overlap. This lack of dorsoventral gradient or patterning could have also influenced branchial arch muscle development in the lamprey. As noted above, sucker/et-1 zebrafish mutants had very poorly developed ventral branchial muscles, although the dorsal muscles were little affected. Expression of sucker/endothelin-1 was limited to the ventral parts of the arch (Miller et al., 2000). If lampreys do lack a comparably restricted pattern, then a ventral branchial musculature would also be lacking, including gill arch depressors comparable to the clavobranchiales/coracobranchiales. Indeed, the more posterior lamprey branchial arches have a musculature including external branchial constrictors, internal dorsal and ventral diagonal constrictors and median muscle bands (adductors) (Roberts, 1950; Mallatt, 1996). A comparable set of muscles is reconstructed for the Osteostraci (Janvier, 1985: fig. 19), and a ventral gill arch musculature is absent.

Another explanation for the absence of both the clavobranchiales/coracobranchiales and the hypobranchial musculature in jawless fishes is based on the unusually anterior position of the pectoral fin in osteostracans, and the influence of the fin on muscle differentiation. As noted above, both branchial and hypobranchial muscles derive from the paraxial mesoderm, as do the muscles of the pectoral fin (Romer \& Parsons, 1986; Ordahl \& Le Douarin, 1992; Schilling \& Kimmel, 1997; reviewed in Hacker \& Guthrie, 1998; Dietrich et al., 1999). This mesoderm occurs in a rostral-caudal series, with the unsegmented caudal cranial paraxial mesoderm (associated with the cranial neural crest) giving rise to the branchial musculature (Schilling \& Kimmel, 1994; Hacker \& Guthrie, 1998) and the more rostral segmented somitic paraxial mesoderm contributing to the hypobranchial and pectoral fin muscles. In chondrichthyans, cells forming the hypobranchial muscles originate from the anterior segmented somites of the paraxial mesoderm, whereas the fin muscles originate separately, from more posterior somites (e.g., Romer \& Parsons, 1986: fig. 196). By comparison, both hypobranchial and pectoral fin muscles originate from the same anterior somites in the zebrafish (Actinopterygii; Neyt et al., 2000), but this is related to the ability of the muscle precursor cells to become separated from the somite and mobile (also in the Amniota (chicks; e.g. Dietrich et al., 1999)). One element of the genetic pathway involved in this mobility is Lbx-1; however, this is not expressed in sharks, which instead show a direct epithelial contribution to fin and hypobranchial muscles (Hildebrand, 1974; Neyt et al., 2000; Haines \& Currie, 2001). If separated and mobile muscle precursor cells are a synapomorphy of the osteichthyans, then 
the chondrichthyan condition may also characterise jawless fishes such as osteostracans (Neyt et al., 2000). In other words, anterior somites would contribute to the hypobranchial musculature, and the more posterior somites to the pectoral fin muscles in these latter groups, with no migration of muscle precursor cells or origin from the same somite (as characterises osteichthyans such as the zebrafish).

More importantly, the position of the pectoral fin bud influences development of the pectoral fin musculature, such that the somites medial to the fin will contribute to its musculature (Christ \& Ordahl, 1995; reviewed in Dietrich et al., 1998). In osteostracans the pectoral fin is anteriorly located, more or less opposite to the otic/occipital region of the braincase, as indicated by the relative positions of the otic capsules and the scapulocoracoid (Janvier, 1996: figs 4.15, 4.16). The anterior position of the osteostracan pectoral fin may have resulted in the contribution of cells from the most anterior somites of the segmented paraxial mesoderm to fin muscle, to the exclusion of a hypobranchial musculature. Thus, a hypobranchial musculature attaching to the lower jaw evolved after the pectoral fin became dissociated from the headshield and more posteriorly positioned, in jawed vertebrates. The anterior position of the osteostracan pectoral fin may also have been responsible for the absence of the coracobranchiales/clavobranchiales branchial muscles responsible for depressing the gill arches. Hacker \& Guthrie (1998) showed that pectoral fin, hypobranchial and branchial muscles differ markedly in their gene expression, suggesting different pathways of muscle development. However, they demonstrated that cells from the segmented paraxial mesoderm grafted into the more anterior region of the cranial paraxial mesoderm were able to migrate to the branchial arches and were incorporated into the muscles associated with these arches. Hacker \& Guthrie (1998) suggested these muscle cells were originally "naive", differentiating and attaining their identity (and particular gene expression) via signals from the surrounding tissues in their target location. Again, this suggests that the anterior position of the pectoral fin in osteostracans may have inhibited cranial mesodermal cells from differentiating into particular branchial muscles, including the gill arch depressors, by instead providing signals for the development of fin musculature.

\section{Conclusions}

Research into feeding and respiration has focused on the muscles depressing the mandible and hyoid arch. Expansion of the oropharyngeal cavity via the lowering of the mandible results in a negative pressure which in turn draws aerated water and food into the mouth cavity. Certain actinopterygians and sarcopterygians possess modifications of this system to improve the expansion of the cavity, the rate of expansion, rate of water/air flow into the cavity and overall suction. However, other taxa lack these modifications, and absent from these discussions has been a consideration of the role of the clavobranchialis/coracobranchialis in improving suction in these taxa. Attachments for the clavobranchialis musculature have been described in fossil sarcopterygians and compared to this muscle in extant actinopterygians. This distribution, and the size of this musculature, particularly in fossil lungfishes, suggests the clavobranchialis had a role in increasing expansion of the oral cavity and osteichthyan feeding and respiration. Direct experimental evidence from chondrichthyans (Motta et al., 1997) indicates that the coracobranchiales muscles are involved in expanding the branchial arches during feeding. Although the coracobranchiales and clavobranchiales have a different innervation, they both derive from paraxial mesoderm, whether cranial and unsegmented (clavobranchiales) or postcranial and segmented into somites (coracobranchiales). Thus, the action of these muscles in feeding and respiration may be a gnathostome synapomorphy, being absent from jawless fishes such as osteostracans.

\section{Acknowledgements}

Materials of the rhizodont Strepsodus were collected at the Middle Paddock site, Queensland. The Hawkins family is thanked for access to their property and making collecting work at the site possible through their invaluable support and hospitality. Dr Tony and Guy Thulborn, and Angus and Tìm Hamley (Queensland Museum) collected the first rhizodont specimens. Help in the field and with preparation has been given by C. Burrow, T. 
Colville, P. Crabb, B. Currie, R. Damiani, J. Ford, J. Garvey, A. Hammerly, S. Howe, L. Masini, K. Parker, C. Northwood, A. Walker and A. Yates. Work on the Ducabrook fossils is supported by Australian Research Council (ARC) grants no. $A 39700915$ and $A 00000629$, and the author is funded by an ARCFellowship. Ashley Edwards provided invaluable assistance in the preparation of Neoceratodus material, and Jean Joss is thanked for provided laboratory space (both Macquarie University). I also thank the Australian Museum for providing access to vehicles and other resources. Ken Campbell, Peter Pridmore, The Royal Society London (Philosophical Transactions of the Royal Society), The Western Australian Museum (Records of the Western Australian Museum), Schweizerbart-Publishers (Palaeontographica A) and Francis \& Taylor Publishers (Fossils and Strata) approved the use of many of the images presented in this paper. Finally, I want to thank Drs Sue Turner and Anne Warren for allowing me to work on the Ducabrook material, and the reviewers Profs $\mathrm{K}$. S. W. Campbell and H. -P. Schultze for valuable comments.

\section{References}

Ahlberg PE, 1991. A re-examination of sarcopterygian interrelationships, with special reference to the Porolepiformes. Zool. J. Linn. Soc. 103: 241-287.

Ahlberg PE, Johanson Z. 1997. The second tristichopterid (Sarcopterygii, Osteolepiformes) from the Upper Devonian of Canowindra, New South Wales, Australia. J. Vert. Paleontol. 17: 653-673.

Ahlberg PE, Johanson Z, Daeschler EB. 2001. The Late Devonian lungfish Soederberghia (Sarcopterygii; Dipnoi) from Australia and North Ameríca, and its biogeographícal implications, $J$ Vert. Paleontol, 21: 1-12.

Alexander RMcN. 1969. Mechanics of the feeding action of a cyprinid fish. $J$ Zool (London) 159: 1-15.

Alexander RMeN. 1970. Mechanics of the feeding action of various teleost fishes. $J$. Zool. (London) 162: 145-156.

Andrews SM. 1973. Interrelationships of crossopterygians. In: Greenwood PH, Miles RS, Patterson C, eds. Interrelationships of Fishes. Zool. J. Linn. Soc. 53 Suppl I: 137-177.

Andrews SM. 1985. Rhizodont crossopterygian fish from the Dinantian of Foulden, Berwickshire, Scotland, with a reevaluation of this group. Trans. $R$. Soc, Edinburgh: Earth Scl. 76: 67-95.

Andrews SM, Westoll, TS. 1970a. The postcranial skeleton of Eusthenopteron foordi Whiteaves. Trans. R. Soc. Edinburgh 68: 207-329.

Andrews SM, Westoll, TS. 1970b. The posteranial skeleton of rhipidistians excluding Eusthenopteron Trans. $R \times$ Soc. Edinburgh 68: 391-489.

Barwick RE, Campbell, KSW. 1996. A Late Devonian dipnoan, Pillararhynchus, from Gogo, Western Australia, and its relationships. Palaeontographica $A$ 239: 1-42.

Bemis WE. 1987. Feeding systems of living Dipnoix Anatomy and Function. $J$. Morphol. Suppl. 1: 249-275.
Bemis WE, Lauder GV. 1986. Morphology and function of the feeding apparatus of the lungfish, Lepidosiren paradoxa (Dipnoi). J. Morphol. 187: 81-108.

Bishop IR, Foxon GEH. 1968. The mechanism of breathing in the South American lungfish Lepidosiren paradoxa; a radiological study. J. Zool. (London) 154: 263-272.

Campbell KSW, Barwick RE. 1987. Paleozoic lungfíshes - a review. J. Morphol. Suppl. 1: 93-131.

Campbell KSW, Barwick RE. 1988a. Uranolophus: a reappraisal of a primitive dipnoan. Inx Jell, PA, ed. Devonian and Carboniferous fish studies. Assoc. Australasian Palaeont. Mem. 7: 87-144.

Campbell KSW, Barwick RE. 1988b. Geological and palaeontological information and phylogenetic hypotheses. Geol. Mag. 125: 207-227.

Campbell, KSW, Barwick RE. 1999. Dipnoan fishes from the Late Devonian Gogo Formation of Western Australia. Rec. West. Australian Mus. Suppl. 57: 107-138.

Campbell, KSW, Barwick RE. 2000. The braincase, mandible and dental structures of the Early Devonian lungfish Dipnorhynchus kurikae from Wee Jasper, New South Wales. Rec. Australian Mus. 52: 103-128.

Chang, M-M. 1991. Head exoskeleton and shoulder girdle of Youngolepis. In: Chang M-M, Liu Y, Zhang G eds. Early Vertebrates and Related Problems of Evolutionary Biology. Beijing: Science Press, 355-378.

Christ B, Ordahl CP. 1995. Early stages of chick somite development, Anat. Embryol. 191: 381-96.

Daniel JF, 1934. The Elasmobranch Fishes. Berkeley: University of California Press.

Dennis K, Miles RS. 1979a. A second eubrachythoracid arthrodire from Gogo, Western Australia. Zool. J. Linn. Soc. 67: 1-29.

Dennis K, Miles RS. 1979b. Eubrachythoracid arthrodires with tubular rostral plates from Gogo, Western Australia. Zool. $J$. Linn. Soc. 67: 297-328.

Dietrich S, Schubert FR, Healy C, Sharpe PT, Lumsden A. 1998. Specification of the hypaxial musculature. Development 125: 2235-2249.

Dietrich S, Abou-Rebyeh F, Brohmann H, Bladt F, Sonnenberg-Riethmacher E, Yamaai T, Lumsden A, Brand-Saberi B, Birchmeier C. 1999. The role of SF/HGF and c-Met in the development of skeletal muscle. Development 126: 16211629.

Edgeworth FH. 1926. On the development of the cranial muscles in Protopterus and Lepidosiren. Trans. R. Soc. Edinburgh 54: 719-734.

Edgeworth FH. 1926. On the development of the cranial muscles in Protopterus and Lepidosiren. Trans. R. Soc. Edinburgh 54: 719-734.

Edgeworth FH. 1935. The Cranial Muscles of Vertebrates. Cambridge: Cambridge University Press.

Forey PJ. 1981. Rhabdoderma in the Carboniferous of the British Isles. Palaeontology 24: 203-229.

Forey PJ. 1998. History of the Coelacanth Fishes. London: Chapman \& Hall. 
Fox RC, Campbell KSW, Barwick RE, Long JA. 1995. A new osteolepiform fish from the Lower Carboniferous Raymond Formation, Drummond Basin, Queensland. Mem. Queensland Mus. 38: 97-223.

Gardiner BG. 1984. The relationships of the palaeoniscid fishes, a review based on new specimens of Mimia and Moythomasia from the Upper Devonian of Western Australia. Bull. Brit. Mus. (Nat. Hist.) Geol. 37: 173-428.

Gillis GB, Lauder GV. 1994. Kinematics of feeding in bluegill sunfish: is there a general distinction between aquatic capture and transport behaviors? J. Exp. Biol. 198: 709-720.

Goujet DF. 1975. Dicksonosteus, un nouvel arthrodire du Dévonien du Spitsberg; remarques sur le squelette viscéral des Dolichothoraci. In: Lehman JP, ed. Problèmes actuels de Paléontologie: Evolution des Vertêbrés. Paris: Colloques Internationaux du Centre National de la Recherche Scientifique, 81-99.

Goujet DF. 2001. Placoderms and basal gnathostome apomorphies. In: Ahlberg PE, ed. Major Events in Early Vertebrate Evolution: Palaeontology, Phylogeny and Development. London: Systematics Association, 209-222.

Günther CA. 1871. Description of Ceratodus, a genus of ganoid fishes, recently discovered in rivers of Queensland, Australia. Trans. R. Soc. London 161: 511-571.

Hacker A, Guthrie, S. 1998. A distinct developmental programme for the cranial paraxial mesoderm in the chick embryo. Development 125: 3461-3472.

Haines L, Currie PD. 2001. Morphogenesis and evolution of vertebrate appendicular muscle. $J$. Anat. 199: 205-209,

Heintz A. 1932. The structure of Dinichthys contribution to our knowledge of the Arthrodira. In: Gudger EW, ed. Archaic Fishes. Bashford Dean Memorial Volume, Article 4, 115224.

Heintz A. 1934. Revision of the Estonian Arthrodira. Part I. Family Homostiidae Jaekel. Publ. Geol. Inst. Univ. Tartu 38: $1-14$.

Hildebrand M. 1974. Analysis of Vertebrate Structure. New York: John Wiley \& Sons.

Janvier P. 1980. Osteolepid remains from the Devonian of the Middle East, with particular reference to the endoskeletal shoulder girdle. In: Panchen AL, ed. The Terrestrial Environment and the Origin of Land Vertebrates. Systematics Association Special Volume 15. London: Academic Press, 223-254.

Janviler P. 1985. Les Cêphalaspides du Spitsberg. Cahìers de Paléontologie (section Vertébrés), Paris: Editions du Centre National de la Recherche Scientifíque.

Janvier P. 1996. Early Vertebrates, Oxford Monographs on Geology and Geophysics 33. Oxford: Oxford Science Publications.

Janvier P. 2001. Ostracoderms and the shaping of the gnathostome characters. In: Ahlberg PE, ed. Major Events in Early Vertebrate Evolution: Palaeontology, Phylogeny and Development. London: Systematics Association, 172-186.

Janvier P, Marcoux J. 1976. Remarques sur la ceinture scapulaire d'un poisson choanate Ostéolépiforme des grès rouges dévoniens de l'Armutgözlek Tepe (Taurus lycìen oriental, Turquie), Compt. rend. Acad. Sci. Paris 283: 619-622.
Jarvik E. 1972. Mĩđdle and Upper Devonian Porolepiformes from East Greenland with special reference to Glyptolepis groenlandica n. sp. Medd. Gron. 187: 1-307.

Jarvik E. 1980. Basic Structure and Evolution of Vertebrates, Volume 1. London: Academic Press.

Jeffery JE, 2001. Pectoral fins of rhizodontids and the evolution of pectoral appendages in the tetrapod stem-group. Biol. J. Linn. Soc, 74: 217-236.

Jessen H. 1966. Die Crossopterygier des Oberen Plattenkalkes (Devon) der Bergisch-Gladbach-Paffrather Mulde (Rheinisches Schiefergebirge) unter Berücksichtigung von americkanischem und europäischem Onychodus-Material. Ark. für Zool. 18: 305-389.

Jessen H. 1972. Schultergürtel und Pectoralflosse bei Actinopterygiern. Fossils Strata 1: 1-101.

Johanson Z. 1997. New Remigolepis (Placodermi; Antiarchi), from Canowindra, NSW, Australia. Geol. Mag. 134; 813-846.

Johanson Z. in review. Placoderm hypobranchial muscles and origins of the gnathostome jaw-lowering musculature. $J$. Vert. Paleo.

Johanson Z,Ahlberg PE. 1997. New tristichopterid (Osteolepíformes: Sarcopterygii) from the Mandagery Sandstone (Famennian) near Canowindra, N.S.W., Australia. Trans. $R$. Soc. Edinburgh Earth Sci. 88: 39-68.

Johanson Z,Ahlberg PE. 1998. A complete primitive rhizodont from Australia. Nature 394: 569-573.

Johanson Z, Ahlberg PE. 2001. Devonian rhizodontids (Sarcopterygii; Tetrapodomorpha) from East Gondwana. Trans. R. Soc. Edinburgh Earth Sci, 92:43-74.

Johanson Z, Turner S, Warren A. 2000. First East Gondwanan record of Strepsodus (Sarcopterygiî; Rhizodontida) from the Lower Carboniferous Ducabrook Formation, Central Queensland, Australia. Geodiversitas 22: 161-169.

Jollie M. 1982. Ventral branchial musculature and synapomorphies questioned. Zool. J. Linn. Soc. 74: 35-47.

Kimmel CB, Miller CT \& Keynes RJ. 2001. Neural crest patterning and the evolution of the jaw. J. Anat. 199: 105119.

Lauder GV. 1979. Feeding mechanisms in primitive teleosts and in the halecomorph fish Amía calva. J. Zool. 187: 543578.

Lauder GV. 1980. Evolution of the feeding mechanism in primitive actinopterygian fishes: A functional anatomical analysis of Polypterus, Lepisosteus and Amia. J. Morphol. 163: 283-317.

Lauder GV. 1982. Patterns of evolution in the feeding mechanism of actinopterygian fishes. Am. Zool. 22: 275-285.

Lauder GV. 1983a. Functional design and evolution of the pharyngeal jaw apparatus in euteleostean fishes. Zool. $J_{x}$ Linn. Soc. 77: 1-38.

Lauder GV. 1983b. Prey capture hydrodynamics în fishes: experimental tests of two models. $J$ Exp. Biol. 104: 1-13.

Lauder GV. 1985. Functional morphology of the feeding mechanísm in lower vertebrates. In: Duncker HR, Fleischer $\mathrm{G}_{\text {, eds. }}$ Functional Morphology of Vertebrates. New York: Springer Verlag, 210-289.

Lauder GV, Liem KF. 1983. The evolution and interrelation- 
ships of the actinopterygian fishes. Bull. Mus. Comp. Zool. 150: $95-197$.

Lauder GV, Shaffer HB. 1985. Functional morphology of the feeding mechanism in aquatic ambystomatid salamanders. J. Morphol. 185: 297-326.

Lebedev O. 1995. A new osteolepid físh from Russia. Bull. Mus. natl Hist. natur. Paris 17: 287-341.

Liem, KF, 1970. Comparative functional anatomy of the Nandidiae (Pisces: Teleostei). Field. Zool. 56: 1m166.

Liem, KF, 1980. Acquisition of energy by teleosts: adaptive mechanisms and evolutionary patterns. In: Alî, MA, ed. Environmental Physiology of Fishes. Plenum Press: New York, 299-334.

Long JA 1987. A redescription of the lungfish Eoctenodus Hills 1929, with reassessment of other Australian records of the genus Dipterus Sedgwick \& Murchison 1828. Rec. West. Australian Mus. 13: 297-314.

Long JA. 1989. A new rhizodontiform fish from the Early Carboniferous of Victoria, Australia, with remarks on the phylogenetic position of the group. $J$ Vert. Paleontol. 9: 117.

Long JA. 1993. Cranial ribs in Devonian lungfishes and the origin of air-breathing. Assoc. Australasian Palaeontols. Mem. 15: 199. 210.

Long JA, Barwick RE, Campbell KSW. 1997. Osteology and functional morphology of the osteolepiform fish Gogonasus andrewsi Long, 1985, from the Upper Devonian Gogo Formation, Western Australia. Rec. West. Australian Mus. Suppl. 53: 1-89.

MeMahon BR. 1969. A functional analysis of the aquatic and aerial respiratory movements of an African lungfísh, Protopterus aethiopicus, with reference to the evolution of the lung-ventilation mechanism in vertebrates. J. Exp. Biol. 51: $407-430$.

Maisey JG. 1989. Visceral skeleton and musculature of a Late Devonian shark, $J$, Vert. Paleontol. 9: 174-190.

Mallatt J. 1996. Ventilation and the origin of jawed vertebrates: a new mouth. Zool. J. Linn. Soc. 117: 329-404.

Miles RS. 1971. The Holonematidae (placoderm fishes), a review based on new specimens of Holonema from the Upper Devonian of Western Australia. Phil, Trans. $R_{\times}$Soc. London 263: 191-234.

Miles RS. 1977. Dipnoan (lungfish) skulls and the relationships of the group: a study based on new species from the Devonian of Australia. Zool. J. Linn. Soc. 61 : 1-328.

Miller CT, Sehilling TF, Lee KH, Parker J, Kimmel CB. 2000. sucker encodes a zebrafish Endothelin-1 required for ventral pharyngeal arch development. Development 127: 38153828.

Miyake T, McEachran J, Hall B. 1992, Edgeworth's legacy of cranial muscle development with an analysis of muscles in the ventral gill arch region of batoid fishes (Chondrichthyes: Batoidea). J. Morph. 212: 213-246.

Morrison SL, Campbell CK, Wright GM. 2000. Chondrogenesis of the branchial skeleton in embryonic sea lamprey, Petromyzon marinus. Anat. Rec. 260: 252-67

Moss SA. 1977. Feeding mechanisms in sharks. Am. Zool. 17: 355-364.
Motta PJ, Trìcas TC, Hueter RE, Summers AP. 1997. Feeding mechanism and functional morphology of the jaws of the lemon shark Negaprion brevirostris (Chondrichthyes, Carcharhinidae). J. Exp. Biol. 200: 2765-2780.

Motta PJ, Wilga CD. 1995. Anatomy of the feeding apparatus of the lemon shark (Megaprion brevirostris). J. Morphol. 226:305-329.

Motta PJ, Wilga CD. 1999. Anatomy of the feeding apparatus of the nurse shark (Ginglymostoma cirratum). $J$. Morphol. 241: 33-60.

Neidert AH, Virupannavar V, Hooker GW, Langeland JA. 2001. Lamprey Dlx genes and early vertebrate evolution. Proc. Natl. Acad. Sci. 98: 1665-1670.

Neyt C, Jagla K, Thisse C, Thisse, B, Haines $\mathbf{L}$, Currie PD. 2000. Evolutionary origins of vertebrate appendicular muscle. Nature 408: 82-86.

Norton SF, Brainerd E. 1993. Convergence in the feeding mechanics of ecomorphologically similar species in the Centrarchidae and Cichlidae. J. Exp. Biol. 176: 11-29.

Ordahl CP, LeDouarin NM. 1992. Two myogenic lineages within the developing somite. Development $114: 339-353$.

Orvig T. 1975. Description, with special reference to the dermal skeleton, of a new radotinid arthrodire from the Gedinnian of Arctic Canada. In: Lehman JP, ed. Problèmes actuels de Paléontologie: Evolution des Vertébrés. Paris: Colloques Internationaux du Centre National de la Recherche Scientifique, 41-72.

Owen R. 1841. Description of the Lepidosiren annectens. Trans. Linn. Soc. Lond. 18: 327-361.

Pridmore PA, Campbell KSW, Barwick RE. 1994. Morphology and phylogenetic position of the holodipteran dipnoans of the Upper Devonian Gogo Formation of northwestern Australia. Phil. Trans. R. Soc. London B 344: 105-164.

Randall DJ. 1972. Respiration. In: Hardisty MW, Potter IC, eds. The Biology of Lampreys. Volume 2. London: Academic Press, 287-306.

Reilly S. M. 1995. The ontogeny of aquatic feeding behavior in Salamandra salamandra: Stereotypy and isometry in feeding kìnematics. J. Exp. Biol. 198: 701-708.

Reilly S. M. 1996. The metamorphosis of feeding kinematics in Salamandra salamandra and the evolution of terrestrial feeding behavior, J. Exp. Biol. 199: 1219-1227.

Reilly SM, Lauder GV. 1990. The evolution of tetrapod feeding behaviour: Kinematic homologies in prey transport. Evolution 44: 1542-1557.

Roberts TDM. 1950. The respiratory movements of the lamprey (Lampetra fluviatilis). Proc. R. Soc. Edinburgh (B) 64: 235-252.

Romer AS, Parsons TS. 1986. The Vertebrate Body. Sixth Edition. Philadelphia: Saunders College Publishing.

Schaeffer B, Thomson, KS. 1980. Reflections on agnathangnathostome relationships. In: Jacobs LL, ed. Aspects of Vertebrate History: Essays in Honor of Edwin Harris Colbert. Flagstaff: Museum of Northern Arizona Press, 19-33.

Schilling TF, Kimmel CB 1994. Segment and cell type lineage restrictions during pharyngeal arch development in the zebrafish embryo. Development 120: 483-494.

Schilling TF, Kimmel CB 1997. Musculoskeletal patterning in 
the pharyngeal segments of the zebrafish embryo. Development 124: 2945-2960.

Schultze H-P. 1975. Dỉe Lungenfísch-Gattung Conchopoma (Pisces, Dipnoi). Senckenb. Lethaea 56: 191-231.

Schultze H-P. 1977. Megapleuron zangerli A new dipnoan from the Pennsylvanian of Illinois. Fieldiana Geol. 33: 375-396.

Schultze H-P. 1987. Dipnoans as sarcopterygians. $J_{x}$ Morphol. Suppl. 1: 39-74.

Schultze H-P, Chorn J. 1998. Sarcopterygian and other fishes from the marine Upper Devonian of Colorado, U.S.A. Mitt. Mus. Naturkunde Berlin Geowiss. Reihe 1: 53-72.

Schultze H-P, Cuumba SL. 2001. Diapilina and the characters of basal actinopterygians. In: Ahlberg PE, ed. Major Events in Early Vertebrate Evolution: Palaeontology, Phylogeny and Development. London: Systematícs Association, 315-332.

Schultze HP, Marshall CR. 1993. Contrasting the use of functional complexes and isolated characters in lungfish evolution Assoc. Australasian Palaeontols. Mem. 15: 211-224.

Shaffer HB, Lauder GV. 1985. Patterns of variation in aquatic ambystomatid salamanders: kinematics of the feeding mechanism. Evolution 39: 83-92.

Stensiö E. 1927. The Downtownian and Devonian Vertebrates of Spitsbergen. Skr. Svalbad Nordishavet 12: 1-391.

Stensiö E. 1959. On the pectoral fin and shoulder girdle of the arthrodires, $K$. Sv. VetenskapsAkad. Handl. 8: 1-229.

Wang S, Drapala V, Barwick RE, Campbell KSW. 1993. The dipnoan species, Sorbitorhynchus deleaskitus, from the Lower Devonian of Guangxi, China. Phil. Trans. $R$. Soc. London (B) 340: 1-24.

Watson DMS, Gill EL. 1923. The structure of certain Paleozoic Dipnoi. Zool. J. Linn. Soc. 35: 163-216.

Wiley EO. 1979. Ventral gill arch muscles and the interrelationships of gnathostomes, with a new classification of the Vertebrata. Zool. J. Linn. Soc. 67: 149-179.

Wilga CD, Motta P. 1998. Feeding mechanism of the Atlantic Guitarfish Rhinobatos lentiginosus: modulation of kinematic and motor activity. J. Exp. Biol. 201: 3167-3184.

Wilga CD, Wainwright PC, Motta P. 2000. Evolution of jaw depression mechanics in aquatic vertebrates: insights from Chondrichthyes. Zool. J. Linn. Soc. 71: 165-185.

Young GC. 1980. A new Early Devonian placoderm from New South Wales, Australia, with a discussion of placoderm phylogeny. Palaeontographica A 167: 1-76.

Zhu M, Schultze H-P. 2001. Interrelationships of basal osteichthyans. In: Ahlberg PE, ed. Major Events in Early Vertebrate Evolution: Palaeontology, Phylogeny and Development. London: Systematics Association, 289-314.

Zhu M, Yu X, Janvier P. 1999. A primitive fossil fish sheds light on the origin of bony fishes. Nature 397: 607-610.

Receivved: 15 January 2002 